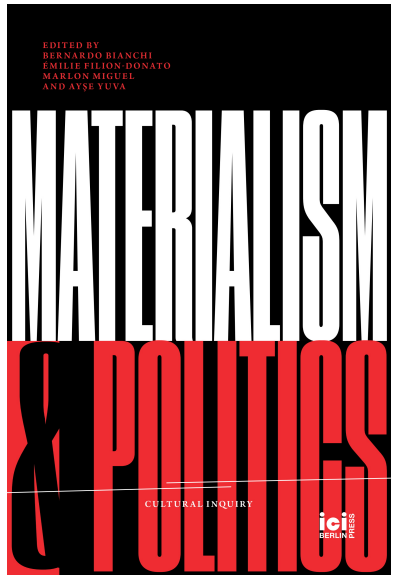

Materialism and Politics, ed. by Bernardo Bianchi, Emilie Filion-Donato, Marlon Miguel, and Ayşe Yuva, Cultural Inquiry, 20 (Berlin: ICI Berlin Press, 2021), pp. 203-14

\section{CORNELIA MÖSER}

\section{Materialism, Matter, Matrix, and Mater

\author{
Contesting Notions in Feminist and Gender Studies
}

CITE AS:

Cornelia Möser, 'Materialism, Matter, Matrix, and Mater: Contesting Notions in Feminist and Gender Studies', in Materialism and Politics, ed. by Bernardo Bianchi, Emilie Filion-Donato, Marlon Miguel, and Ayşe Yuva, Cultural Inquiry, 20 (Berlin: ICI Berlin

Press, 2021), pp. 203-14 <https://doi.org/10.37050/ci-20_11>

\section{RIGHTS STATEMENT:}

\author{
(C) by the author(s) \\ Except for images or otherwise noted, this publication is licensed \\ under a Creative Commons Attribution-ShareAlike 4.0 Interna- \\ tional License.
}

ABSTRACT: This chapter compares two strands of thought that experienced a difficult translation into the French context: new materialism (NM) and the gender debates within feminism. In this chapter, I analyse the different notions of material, materialism, or materiality at stake in various NM approaches. Following this, I show that socialist feminism, materialist feminism, and NM only share a rejection of postmodernism and anti-naturalism. I claim that the very different understandings of materialism within these feminisms must have contributed to this tepid reception of new materialism in France.

KEYWORDS: new materialism; materialist feminism; French feminism; class and gender; structuralism; post-humanist ontology; social structure; institutions 


\section{Materialism, Matter, Matrix, and Mater Contesting Notions in Feminist and Gender Studies CORNELIA MÖSER}

\section{INTRODUCTION}

Under the label of new materialism (NM), a number of scholars, who mostly come from the United States - specifically, from the University of Chicago - as well as from several Northern and Central European countries, have published and defended a scientific approach that they characterize as new and materialist. This approach is among other fields mostly rooted in science and technology studies (STS) and in philosophy. It grapples with the idea of the existence and potential agency of a material world beyond human perception. This approach reached its peak in the early 2010s and then gradually lost influence, although it should be said that it was a rather marginal phenomenon from the start. Surprisingly, in France, where the strongest scientific branch of feminism is a materialist one, NM is almost unknown. Considering the numerous French references of NM, this absence and non-translation recalls the feminist gender debates in France and Germany. Whereas Judith Butler's Gender Trouble was translated into German one year after the publication of the original, it took fifteen years before it was translated into French. ${ }^{1}$ Although NM

1 Judith Butler, Gender Trouble: Feminism and the Subversion of Identity (New York: Routledge, 1990); Judith Butler, Das Unbehagen der Geschlechter (Frankfurt a.M.: 
claims to be an alternative to post-structuralism, its reception (or lack thereof) in France shows that it cannot be understood as the returning spectre of Marxism or of materialist feminism.

\section{WHAT'S NEW IN NEW MATERIALISM?}

A series of publications, books, articles, and conferences introduced and discussed NM around 2008. In a recent publication in France, I presented NM to a French speaking audience and compared it to materialist feminism in France. ${ }^{2}$ The books I analysed for that purpose showed that nuances in notions of materialism exist theoretically, politically, and in disciplinary projects, and each of these aspects needs to be considered in order to gain an understanding of the nonreception of NM in France. The first collection I analysed, Material Feminisms, which was edited by Susan Hekman and Stacy Alaimo and published in $2008,{ }^{3}$ focuses on ecofeminism and calls for a transvaluation of nature. Criticizing postmodern feminism for having gone too far in rejecting nature in its attempt to also reject biological explanations of male domination, the editors of this volume argued that (feminist) research should concentrate on the natural world and the human body. In their view, postmodernism wrongfully privileged culture over nature, and so they argued for the deconstruction of the opposition between nature and culture and for investigation into what they call, for example, transcorporeality. That term signifies the connection of bodies with each another and with other creatures, types of matter, and landscapes. ${ }^{4}$ In her review of the book, the materialist, feminist historian Jana Tschurenev observed a discrepancy between the book's project and the actual research represented in the collection.

Suhrkamp, 1991); Judith Butler, Trouble dans le genre. Pour un féminisme de la subversion (Paris: La Découverte, 2005); Cornelia Möser, Féminismes en traductions. Théories voyageuses et traductions culturelles (Paris: Éditions des archives contemporaines, 2013).

2 Cornelia Möser, 'Néo-Matérialisme. Un nouveau courant féministe?', in Matérialismes, cultures et communication, ed. by Maxime Cervulle, Nelly Quemener, and Florian Vörös (Paris: Presses des Mines, 2016), pp. 227-44.

3 Material Feminisms, ed. by Stacy Alaimo and Susan J. Hekman (Bloomington: Indiana University Press, 2008).

4 Stacy Alaimo, Bodily Natures: Science, Environment, and the Material Self (Bloomington: Indiana University Press, 2010). 
Most of the research, she noted, came from literature studies and not from a greater variety of disciplines. As a result, she thought that the contributions failed to consider social structures, the state, and other social and political institutions, as well as social movements. ${ }^{5}$

The second collective volume I analysed was edited by Diana Coole and Samantha Frost in 2010 under the title New Materialisms and shared some concerns with the ethics of science and ecofeminist perspectives. ${ }^{6}$ However, the collection reduced feminist perspectives to just one approach among many others. The notion of materialism present in this volume was not linked to historical materialism and instead expressed a strong belief in the ethics of science and, most of all, in the impact the natural sciences should have on social and material change. The authors did not analyse science as a sociopolitical formation, and instead of questioning the division of research into the natural sciences and the humanities, they tried to apply the knowledge of the natural sciences to the humanities. They focused on the agency of matter and affirmed a 'new posthumanist ontology' that should break with neo-Marxist and critical theory. The latter tradition is, in their view, too negative and critical, and so for their more positive project they turned to the writings of Baruch Spinoza, Gilles Deleuze, and Michel Foucault.

The third collection I analysed was edited by Iris van der Tuin and Rick Dolphijn and published in 2012 under the title New Materialism. ${ }^{7}$ The use of the singular noun as opposed to the plural of New Materialisms used in the previous collection marks this project as a conceptual and philosophical one. It gathered texts and interviews with the professed aim of inquiring into the ideal and material constitution of the world. What the authors aimed to understand was the reciprocal production of what is in the world and the things we know about the things in the world. Their epistemological project was presented as a philosophy of difference, which might recall postmod-

5 Jana Tschurenev, 'Review of "Material Feminisms" by Susan Hekman and Stacy Alaimo', Das Argument, 52.287 (2010), pp. 414-16.

6 New Materialisms: Ontology, Agency, and Politics, ed. by Diana Coole and Samantha Frost (Durham, NC: Duke University Press, 2010).

7 Rick Dolphijn and Iris van der Tuin, New Materialism: Interviews \& Cartographies (Ann Arbor, MI: Open Humanities Press, 2012) <https://doi.org/10.3998/ohp. 11515701.0001.001>. 
ernism. However, instead of focusing on the construction of difference on a symbolic level, they, too, focused on the agency of matter.

Contrary to the Frost/Coole collection, van der Tuin and Dolphijn very much emphasize their inscription in a feminist project of knowledge, but their feminism concentrates on the works of Rosi Braidotti, Elizabeth Grosz, Luce Irigaray, and Simone de Beauvoir. They, too, do not discuss socialist, materialist, or Marxist feminism. Their 'close reading' of Beauvoir presents her as a French feminist and inscribes Beauvoir into their own project of the philosophy of difference. In doing so, they radically erase Beauvoir's own claim to existentialist philosophy as well as, ironically, her strong opposition to the philosophies of difference in French feminism in the late 1970s and early $1980 \mathrm{~s}^{8}$ Their motivation for this specific reading lies in Beauvoir's notion of the flesh, which, according to the authors, allows for an ontogenesis which serves as an alternative to the opposition of two competing views on gender: naturalism and constructivism. While in naturalism sex would determine gender, in constructivism it is the other way around: gender would determine sex. Dissatisfied with both, the NM of van der Tuin and Dolphijn refutes feminist oppositions to sexual difference and calls for affirming sexual difference and showing sexual differing. Feminism understood in terms of differing would push sexual differences to the extreme and help transcend the nature/culture binary by opting for a monism. Furthermore, this monism is filled with the hopes of transcending anthropocentrism, which, according to the authors, limits human perception. It remains unclear, though, how exactly they wish to access the non-human world and its agency without relying on their own human point of view.

In spite of their more or less close relationships to feminist science, and in spite of their differing perspectives (STS and epistemological), all of these projects have several points in common:

- their attempt to go beyond postmodernism, which is sometimes almost an attack on postmodernist approaches.

8 Simone de Beauvoir was one of the founders of the journal Questions Féministes, later Nouvelles Questions Féministes, which was the declared counter-part to the Antoinette Fouque style of feminism in the group Psychanalyse et Politique. 
- their understanding of materialism as the study of the material world, that is, of the relationship between words and things.

- their interest in finding out more about the agency of matter that lies beyond human perception.

- their disregard of earlier feminist engagements with materialism, such as socialist, materialist, or Marxist feminism.

This quite schematic presentation nonetheless gives us some elements that are helpful in understanding why there has been no exchange between French materialist feminism and NM(s). If we look back at the history of feminist theory, at least in France, Germany, and the US, which are the contexts I am most familiar with, we need to clarify a number of terms and explain their historical meaning in order to grasp feminist engagements with materialism in the past.

Most of the first attempts to theorize women's oppression in the 1970s started from a historical materialist background and borrowed from Marxist vocabulary and concepts. Among these, one finds Marxist feminism, socialist feminism, materialist feminism, and radical feminism. Marxist feminism is interested in the gendered patterns of capitalism but views gender oppression and capitalism as one social system. In other words, according to Marxist feminism there cannot be any women's emancipation within capitalism. In order to liberate themselves, women not only have to get rid of the patriarchy but capitalism as well. Socialist feminists like Silvia Federici, Josette Trat, or Frigga Haug ${ }^{9}$ also view patriarchy and capitalism as interwoven, but through their focus on how the accumulation process relies on reproductive work, they have also shown capitalisms' dependency on patriarchy. Still, for the socialist feminists as well, there can be no partial liberation because both systems are linked.

In her introduction to feminist theory, Linda Nicholson proposes to differentiate between one-system and two-system models. Marxist

9 Silvia Federici, Revolution at Point Zero: Housework, Reproduction, and Feminist Struggle (Oakland, CA: PM Press, 2012); Josette Trat, Les Cahiers du féminisme (1977-1988): Vingt ans dans le tourbillon du féminisme et de la lutte des classes (Paris: Syllepse, 2011); Frigga Haug and Kornelia Hauser, 'Marxistische Theorien und feministischer Standpunkt', in Traditionen Brüche. Entwicklungen feministischer Theorie, ed. by Gudrun-Axeli Knapp and Angelika Wetterer (Freiburg: Kore, 1992), pp. 115-49. 
and socialist feminisms are examples of one-system models. ${ }^{10}$ Radical feminism and materialist feminism, on the contrary, are two-system models, because they consider that there can be important change in the patriarchal order without overcoming capitalism. It is not so much that they do not want to overcome capitalism, but rather that they refuse to wait on the revolution for significant change to happen in women's lives. Not only have these two-system models criticized persistent male domination in socialist countries, which relativizes the promise that the patriarchy would disappear with the end of capitalism, but they also claim that ending the oppression of women is an aim in itself; it does not need to be ennobled by inscribing it into the struggle against capitalism.

Radical feminism is also clearly inspired by the US Civil Rights Movement, from which it borrowed both terminology (sexism developed as an analogy to racism) and praxis (consciousness-raising groups). Materialist feminism in France is closer to the two-system model of radical feminism than it is to socialist or Marxist feminism. Sociologist Christine Delphy, a key figure of materialist feminism in France, has been strongly criticized for her concept of sex classes ${ }^{11}$ that comes from Friedrich Engels ${ }^{12}$ and was taken up by Virginia Woolf, ${ }^{13}$ Simone de Beauvoir, ${ }^{14}$ and, later, by Kate Millett, ${ }^{15}$ Ti-Grace Atkinson, ${ }^{16}$ Shulamith Firestone, ${ }^{17}$ and the Radicalesbians. Engels conceived of women as the proletariat and men as the bourgeois, which proved to be an inspiring formula for early feminist theory. Delphy's and other materialist feminist's notion of materialism insists on the material grounds and effects of women's oppression. They do so in

10 The Second Wave: A Reader in Feminist Theory, ed. by Linda Nicholson (New York: Routledge, 1997).

11 Geschlechterverhältnisse und Frauenpolitik, ed. by Projekt sozialistischer Feminismus (Berlin: Argument, 1984).

12 Friedrich Engels, Der Ursprung der Familie, des Privateigentums und des Staats: im Anschluß an Lewis H. Morgans Forschungen (Zürich: Hottingen, 1884).

13 Virginia Woolf, Three Guineas (London: Hogarth Press, 1938).

14 Simone de Beauvoir, Le Deuxième Sexe (Paris: Gallimard, 1949).

15 Kate Millett, Sexual Politics (New York: Doubleday, 1970).

16 Ti Grace Atkinson, Amazon Odyssey: The First Collection of Writings by the Political Pioneer of the Women's Movement Ti-Grace Atkinson (New York: Links Books, 1974).

17 Shulamith Firestone, The Dialectic of Sex: The Case for Feminist Revolution (New York: Morrow, 1970). 
order to oppose feminist approaches that conceive of women's oppression as belonging to only the symbolic order or as only a question of behaviour and traditional roles. For such thinkers it was crucial to show the economic exploitation of women by men.

Socialist feminists like Mary McIntosh and Frigga Haug have pointed out the limits of the sex class concept already in the early 1980s. Elsewhere I argued that the notion of sex classes replaces social classes and that, therefore, materialist feminists see no difference between a working woman and a bourgeois woman. Yet for Delphy, women are always defined by their male partners: women do not belong to social classes, they form a class of their own. For Delphy, bourgeois women are mere luxury prostitutes that stand and fall at the will of their husbands and rarely own anything themselves. ${ }^{18}$ Maira Abreu has shown that materialist feminists like Delphy and other authors from the Questions féministes journal collective actually called themselves radical feminists up to the late 1970 s. ${ }^{19}$ This re-labelling has caused a deal of confusion today as some now wrongfully suspect there is a proximity between materialist feminism and socialist or Marxist feminism. While it is true that materialist feminism is interested in exploitation and the material ground of women's oppression, it is also true that this type of feminism marks a point of rupture with the socialist and Marxist left in France, as - contrary to the former group's position - socialist and Marxist feminists have always remained close to an anticapitalistic politics. In like manner, NM creates some confusion because it resembles neither of the two models, as it is neither a onenor a two-system model. It does not resemble radical nor socialist feminism. In order to understand what is new in NM, we need to take a closer look at their notion of materialism.

18 Christine Delphy, 'Nos amis et nous. Les Fondements cachés de quelques discours pseudo-féministes', Questions féministes, 1 (1977), pp. 20-49 (p. 41). She is not the only one to observe that heterosexual women's status often depends on their husband's status. Recent sociological studies show that for bourgeois women, this is still very often the case, cf. Le Collectif Onze, Au tribunal des couples: Enquête sur des affaires familiales (Paris: Odile Jacob, 2013), p. 312.

19 Maira Abreu, 'De quelle histoire le "féminisme matérialiste" (français) est-il le nom?', in Matérialismes féministes, ed. by Maxime Cervulle and Isabelle Clair (= Comment s'en sortir?, 4 (2017)), pp. 55-79. 


\section{NOTIONS, THEIR MEANINGS, AND THEIR MATERIALITY}

The political project of historical Marxism was compelling for many feminists. The materialist, feminist translation of the historical Marxist project was to name the exploitation of women by men and criticize the ideology of bourgeois love that made women consent to their exploitation. Yet, Marxism had its own analysis of women's oppression ${ }^{20}$ that converged with feminism in the critique of the bourgeois family. The Frankfurt school took up Wilhelm Reich's Freudian-Marxism and produced a number of theories on women's oppression (Leo Löwenthal on Henrik Ibsen, Max Horkheimer on motherhood, Herbert Marcuse and Erich Fromm on sexuality, and even Theodor Adorno was tempted by an analysis of women as merchandise). ${ }^{21}$ While part of feminist research in Germany took up these works and tried to use their less sexist parts for their own theories, ${ }^{22}$ large parts of radical feminism in the 1970s struggled to break with the Freudian-Marxist framework, which they found barely sufficient to explain women's oppression, and ended up forming new alliances with post-structuralism. This story has been told by Cornelia Klinger in terms of a 'marriage,, 23 but ob-

20 August Bebel, Die Frau und der Sozialismus (Zürich: Hottingen, 1879); Wilhelm Reich, Die Sexualität im Kulturkampf (Copenhagen: Sexpol, 1936).

21 Leo Löwenthal, 'Das Individuum in der individualistischen Gesellschaft. Bemerkungen über Ibsen', Zeitschrift für Sozialforschung, 5.3 (1936), pp. 321-63; Eva-Maria Ziege, "The Fetish-Character of "Woman": On a Letter from Theodor W. Adorno to Erich Fromm Written in 1937', Logos, 2.4 (2003) <http://www.logosjournal. com/issue2.4.pdf>; Herbert Marcuse, Eros and Civilization: A Philosophical Inquiry into Freud (Boston: Beacon Press, 1955); and Max Horkheimer, 'Egoismus und Freiheitsbewegung: Zur Anthropologie des bürgerlichen Zeitalters', Zeitschrift für Sozialforschung, 5.2 (1936), pp. 161-234.

22 See, for example, Ursula Beer, Klasse. Geschlecht. Feministische Gesellschaftsanalyse und Wissenschaftskritik (Bielefeld: AJZ Verlag, 1987); or Regina Becker-Schmidt, 'Die doppelte Vergesellschaftung - die doppelte Unterdrückung: Besonderheiten der Frauenforschung in den Sozialwissenschaften', in Die andere Hälfte der Gesellschaft. Österreichischer Soziologentag 1985. Soziologische Befunde zu geschlechtsspezifischen Formen der Lebensbewältigung, ed. by Lilo Unterkirchner and Ina Wagner (Vienna: ÖGB Verlag, 1987), pp. 10-25. Much later there was a similar attempt by feminists in France: Adorno critique de la domination. Une lecture féministe, ed. by Eleni Varikas, Nicole Gabriel, and Sonia Dayan-Herzbrun (= Tumultes, 23 (2004)).

23 See Cornelia Klinger, 'Liberalismus - Marxismus — Postmoderne. Der Feminismus und seine glücklichen oder unglücklichen "Ehen" mit verschiedenen Theorieströmungen im 20. Jahrhundert', in Kritische Differenzen - geteilte Perspektiven. Zum Verhältnis von Feminismus und Postmoderne, ed. by Antje Hornscheidt, Gabriele Jähnert, and Annette Schlichter (Wiesbaden: Westdeutscher Verlag, 1998), pp. 18-41. Klinger dis- 
viously the marriage metaphor obscures the important ways in which feminists have actually contributed to building what was later called post-structuralism. Nevertheless, feminist postmodern theory had its day from the late 1980 s to the early 2000 s and the new materialist project is a declared attempt to end what they view as the dominance of postmodern theory in academia. ${ }^{24}$ However, as we can understand through the analysis of the different forms of feminism and of materialism, NM is probably closest to the theoretical strand it criticizes: postmodernism.

If you try to understand what this school of 'postmodernism' these thinkers oppose actually is, the only reference you will find is to Butler's work. Had their notions of materialism not been so different, new materialists could have joined materialist feminist's critique of Butler and gender theory. NM criticizes postmodern theory for not reflecting on its own implications in modernism. However, NM does not seem to reflect upon its own postmodernist implications and clearly lacks basic engagement with other forms of feminist materialism. Had NM not been so opposed to Butler, they would have actually noticed that she, too, has been working on the notion of agency in her exchanges with Saba Mahmood and Talal Asad. ${ }^{25}$ Nevertheless, these exchanges do not really match those of inquiring into whether fossils can be seen as a proof of the agency of matter. ${ }^{26}$

In her work on NM, Pia Garske has undertaken a comparison between NM and historical materialism. For her, these two schools are similar in their efforts against essentialism, and yet she highlights important differences in their perspectives on social humanity. Garske shows how historical materialism distinguishes between

cusses the various unhappy marriages of feminism and concludes that feminism is not an appropriate bride for postmodernism. While this argument certainly hinges on the definition of feminism one employs, Klinger is right that Butler's alliance with postmodern theory was devastating for a certain type of radical feminism.

24 See Material Feminisms, ed. by Hekman and Alaimo, pp. 1-5; Coole and Frost, New Materialisms, pp. 2 and 6; or Dolphijn and van der Tuin, New Materialism, p. 91.

25 See Talal Asad, Wendy Brown, Judith Butler, and Saba Mahmood, Is Critique Secular? Blasphemy, Injury, and Free Speech (New York: Fordham University Press, 2013); and Saba Mahmood, The Politics of Piety: The Islamic Revival and the Feminist Subject (Princeton, NJ: Princeton University Press, 2005).

26 Dolphijn and van der Tuin, 'Interview with Quentin Meillassoux', in New Materialism, pp. 71-84. 
agency (Handlungsfähigkeit) and efficiency (Wirkmächtigkeit), which clearly seem to be one and the same thing for NM. ${ }^{27}$ While Handlungsfähigkeit asks whether someone has the capacity to act, Wirkmächtigkeit asks, on the one hand, whether someone or something has an impact, which introduces the question of power once we discuss this quality in relation with humans (there is Mächtigkeit in Wirkmächtigkeit, that is the question of Macht, of power). The term also includes the impact a thing or a substance can have on its environment. This distinction between Handlungsfähigkeit and Wirkmächtigkeit also brings up the question of intentionality. A substance does not choose to impact its environment the way a human can choose to go on strike. But these differentiations might explain why new materialists could not take part in ongoing feminist debates on agency, because these debates almost exclusively focus on the Handlungsfähigkeit-side of the issue while the interest of the $\mathrm{NW}(\mathrm{s})$ is clearly limited to the Wirkmächtigkeits-side of agency. Or, to put it more clearly, so far feminist theory has mostly been interested in women's capacity to act in a world that is organized to deny their subjective existence.

\section{CONCLUSION}

The new materialist project is mostly interesting for its attempt to renew and challenge feminist understandings of nature. It is true that the necessary rejection of nature in feminism, which arose from the misogynistic practices of relegating women to the nature part of the nature/culture binary, as well as the modernist grounding of women's oppression in their supposedly 'naturally' inferior disposition, has created quite a rift between feminism and nature. A renewed interest in the material world had already been attempted by ecofeminists who were almost exclusively socialist feminists (Maria Mies, Vandana Shiva, ${ }^{28}$ Françoise d'Eaubonne. ${ }^{29}$ Sadly, the NM(s) have not embraced this legacy. The same is true for the rich and strong tradition of feminist theory of embodiment (Iris Marion Young, Sandra Lee Bartky, Susan Bordo, Ann Cahill). It seems that in the same way that many

27 Garske, What's the Matter.

28 Maria Mies and Vandana Shiva, Ecoféminisme (Paris: L'Harmattan, 1998).

29 Françoise d'Eaubonne, Le Féminisme ou la mort (Paris: Pierre Horay, 1974). 
feminists needed to break with nature and the body, new materialists somehow needed to break with most feminist materialist theories. Particularly in the 1970s and 1980s those that were later labelled French feminists undertook an inquiry into feminist ways of perceiving the body. In Germany, Barbara Duden, Gerburg Treusch-Dieter, and Gesa Lindemann ${ }^{30}$ have pursued an analysis of the body from their own perspectives. ${ }^{31}$ Bodily materiality was one of the central questions in the German 'Butler Debates' of the early 1990s. ${ }^{32}$

New materialist's call to take on ecological and bodily issues might also have contributed to their difficulty in being received by feminist research in France, because the majority of that research is working to counter naturalist sexism. And yet, NM's proposition to practically undertake the project of rethinking nature is quite deceptive because they also systematically refuse to see the sociopolitical implications of nature. Frieder Otto Wolf has criticized the nature-culture binary and called for a realistic view of our existence as natural beings ${ }^{33}$ which would involve understanding humanity's 'natural' side, our dependence on nature's agency, but also the unintended effects of our own actions. NM's exclusion of all of humanity from 'nature' as well as its refusal to see humans as sociopolitical beings that are involved in creating institutions, ideologies, concepts, and tools has led to new materialists falling back upon the exact same dualism of nature-culture that they claim to transcend. This is also valid for their uncritical reproduction of the division of science into natural science and the humanities. This division is itself the product of sociopolitical struggles and expresses a power relation as much as the criticized humanities' divided world view does. The new materialist's project of understanding the reflexive foundations of the naturalization of social relations is extremely

30 Gesa Lindemann, 'Die leiblich-affektive Konstruktion des Geschlechts. Für eine Mikrosoziologie des Geschlechts unter der Haut', Zeitschrift für Soziologie, 21 (1992), pp. 330-46.

31 Barbara Duden, Geschichte unter der Haut. Ein Eisenacher Arzt und seine Patientinnen um 1730 (Stuttgart: Klett-Cotta, 1987); Gerburg Treusch-Dieter, 'Von der Antinorm zur Norm. Neuere Perspektiven weiblicher Sexualität', in her Von der sexuellen Rebellion zur Gen- und Reproduktionstechnologie (Tübingen: Gehrke, 1990), pp. 140-67.

32 Möser, Féminismes en traduction, pp. 176-85.

33 Frieder Otto Wolf, 'Wider die Kategorie der gesellschaftlichen Naturverhältnisse', Das Argument, 50.279 (2008), pp. 867-72. 
important, but, in order to have this project succeed, the social and political relations cannot be ignored.

NM might also be viewed as a clever survival strategy connecting the humanities to the natural sciences, which could save the humanities from being abolished. While this strategy, if it is one, would be understandable, it does bear the risk of reaffirming the problematic division of science into these two parts. One can glean a fetishization of the natural sciences from many new materialist writings in exactly their presentation of the natural sciences as the 'actual' science, with humanities playing the supporting role of commentary.

Feminist research began in the early 1980 s as a project to radically change not only the universities and science but society as a whole. ${ }^{34}$ The different epistemological attempts to reach that goal included standpoint theory and the notion of strong objectivity from thinkers such as Evelyn Fox Keller, Sandra Harding, and Donna Haraway, among others. Haraway is actually the only socialist feminist to be claimed by the new materialists, but all of the socialist feminist impulses in her work are stripped away in order to make her another humanist observant of science. Confronting NM with a feminist and socialist critique of science would allow for a better understanding of science as a sociopolitical process, which is organized by institutions, and which mediates the knowledge it produces. ${ }^{35}$

34 Gisela Bock, 'Frauenbewegung und Frauenuniversität - Zur politischen Bedeutung der Sommeruniversität', in Frauen und Wissenschaft. Beiträge zur Berliner Sommeruniversität für Frauen, Juli 1976, ed. by Gruppe Berliner Dozentinnen (Berlin: Courage, 1977), pp. 15-22 (p. 22).

35 Émilie Filion-Donato's contribution to this volume undertook such a promising confrontation. 
Cornelia Möser, 'Materialism, Matter, Matrix, and Mater: Contesting Notions in Feminist and Gender Studies', in Materialism and Politics, ed. by Bernardo Bianchi, Emilie Filion-Donato, Marlon Miguel, and Ayşe Yuva, Cultural Inquiry, 20 (Berlin: ICI Berlin Press, 2021), pp. 203-14 <https://doi.org/10. $37050 / \mathrm{ci}-20 \quad 11>$

\section{REFERENCES}

Abreu, Maira, 'De quelle histoire le “féminisme matérialiste” (français) est-il le nom?', in Matérialismes féministes, ed. by Maxime Cervulle and Isabelle Clair (= Comment s'en sortir?, 4 (2017)), pp. 55-79

Alaimo, Stacy, Bodily Natures: Science, Environment, and the Material Self (Bloomington: Indiana University Press, 2010)

Alaimo, Stacy, and Susan J. Hekman, eds, Material Feminisms (Bloomington: Indiana University Press, 2008)

Asad, Talal, Wendy Brown, Judith Butler, and Saba Mahmood, Is Critique Secular? Blasphemy, Injury, and Free Speech (New York: Fordham University Press, 2013) <https://doi.org/ 10.5422/fordham/9780823251681.001.0001>

Atkinson, Ti Grace, Amazon Odyssey: The First Collection of Writings by the Political Pioneer of the Women's Movement Ti-Grace Atkinson (New York: Links Books, 1974)

Beauvoir, Simone de, Le Deuxième Sexe (Paris: Gallimard, 1949)

Bebel, August, Die Frau und der Sozialismus (Zürich: Hottingen, 1879)

Becker-Schmidt, Regina, 'Die doppelte Vergesellschaftung - die doppelte Unterdrückung: Besonderheiten der Frauenforschung in den Sozialwissenschaften', in Die andere Hälfte der Gesellschaft. Österreichischer Soziologentag 1985. Soziologische Befunde zu geschlechtsspezifischen Formen der Lebensbewältigung, ed. by Lilo Unterkirchner and Ina Wagner (Vienna: ÖGB Verlag, 1987), pp. 10-25

Beer, Ursula, Klasse, Geschlecht. Feministische Gesellschaftsanalyse und Wissenschaftskritik (Bielefeld: AJZ Verlag, 1987)

Bock, Gisela, 'Frauenbewegung und Frauenuniversität - Zur politischen Bedeutung der Sommeruniversität', in Frauen und Wissenschaft. Beiträge zur Berliner Sommeruniversität für Frauen, Juli 1976, ed. by Gruppe Berliner Dozentinnen (Berlin: Courage, 1977), pp. $15-22$

Butler, Judith, Gender Trouble: Feminism and the Subversion of Identity (New York: Routledge, 1990)

Trouble dans le genre. Pour un féminisme de la subversion (Paris: La Découverte, 2005)

Das Unbehagen der Geschlechter (Frankfurt a.M.: Suhrkamp, 1991)

Coole, Diana, and Samantha Frost, eds, New Materialisms: Ontology, Agency, and Politics (Durham, NC: Duke University Press, 2010) <https://doi.org/10.1215/ 9780822392996>

Delphy, Christine, 'Nos amis et nous. Les Fondements cachés de quelques discours pseudoféministes', Questions féministes, 1 (1977), pp. 20-49 
Dolphijn, Rick, and Iris van der Tuin, New Materialism: Interviews \& Cartographies (Ann Arbor, MI: Open Humanities Press, 2012) <https://doi.org/10.3998/ohp.11515701. 0001.001>

Duden, Barbara, Geschichte unter der Haut. Ein Eisenacher Arzt und seine Patientinnen um 1730 (Stuttgart: Klett-Cotta, 1987)

d'Eaubonne, Françoise, Le Féminisme ou la mort (Paris: Pierre Horay, 1974)

Engels, Friedrich, Der Ursprung der Familie, des Privateigentums und des Staats: im Anschluß an Lewis H. Morgans Forschungen (Zürich: Hottingen, 1884)

Federici, Silvia, Revolution at Point Zero: Housework, Reproduction, and Feminist Struggle (Oakland, CA: PM Press, 2012)

Filion-Donato, Émilie, 'Psychodynamism of Individuation and New Materialism: Possible Encounters', in Materialism and Politics, ed. by Bernardo Bianchi, Emilie Filion-Donato, Marlon Miguel, and Ayşe Yuva, Cultural Inquiry, 20 (Berlin: ICI Berlin Press, 2020), pp. 233-52 <https://doi.org/10.37050/ci-20 13>

Firestone, Shulamith, The Dialectic of Sex: The Case for Feminist Revolution (New York: Morrow, 1970)

Haug, Frigga, and Kornelia Hauser, 'Marxistische Theorien und feministischer Standpunkt', in Traditionen Brüche. Entwicklungen feministischer Theorie, ed. by Gudrun-Axeli Knapp and Angelika Wetterer (Freiburg: Kore, 1992), pp. 115-49

Horkheimer, Max, 'Egoismus und Freiheitsbewegung: Zur Anthropologie des bürgerlichen Zeitalters', Zeitschrift für Sozialforschung, 5.2 (1936), pp. 161-234<https://doi.org/10. 5840/zfs 19365273>

Klinger, Cornelia, 'Liberalismus - Marxismus - Postmoderne. Der Feminismus und seine glücklichen oder unglücklichen "Ehen” mit verschiedenen Theorieströmungen im 20. Jahrhundert', in Kritische Differenzen - geteilte Perspektiven. Zum Verhältnis von Feminismus und Postmoderne, ed. by Antje Hornscheidt, Gabriele Jähnert, and Annette Schlichter (Wiesbaden: Westdeutscher Verlag, 1998), pp. 18-41 <https://doi.org/10.1007/978-3322-89056-6 1>

Le Collectif Onze, $\bar{A} u$ tribunal des couples: Enquête sur des affaires familiales (Paris: Odile Jacob, 2013)

Lindemann, Gesa, 'Die leiblich-affektive Konstruktion des Geschlechts. Für eine Mikrosoziologie des Geschlechts unter der Haut', Zeitschrift für Soziologie, 21 (1992), pp. 330-46

Löwenthal, Leo, 'Das Individuum in der individualistischen Gesellschaft. Bemerkungen über Ibsen', Zeitschrift für Sozialforschung, 5.3 (1936), pp. 321-63 <https://doi.org/10.5840/ zfs 1936531>

Mahmood, Saba, The Politics of Piety: The Islamic Revival and the Feminist Subject (Princeton, NJ: Princeton University Press, 2005)

Marcuse, Herbert, Eros and Civilization: A Philosophical Inquiry into Freud (Boston: Beacon Press, 1955)

Mies, Maria, and Vandana Shiva, Ecoféminisme (Paris: L'Harmattan, 1998)

Millett, Kate, Sexual Politics (New York: Doubleday, 1970)

Möser, Cornelia, Féminismes en traductions. Théories voyageuses et traductions culturelles (Paris: Éditions des archives contemporaines, 2013)

_ 'Néo-Matérialisme. Un nouveau courant féministe?', in Matérialismes, cultures et communication, ed. by Maxime Cervulle, Nelly Quemener, and Florian Vörös (Paris: Presses des Mines, 2016), pp. 227-44

Nicholson, Linda, ed., The Second Wave: A Reader in Feminist Theory (New York: Routledge, 1997)

Projekt sozialistischer Feminismus, ed., Geschlechterverhältnisse und Frauenpolitik (Berlin: Argument, 1984)

Reich, Wilhelm, Die Sexualität im Kulturkampf (Copenhagen: Sexpol, 1936) 
Trat, Josette, Les Cahiers du féminisme (1977-1988): Vingt ans dans le tourbillon du féminisme et de la lutte des classes (Paris: Syllepse, 2011)

Treusch-Dieter, Gerburg, 'Von der Antinorm zur Norm. Neuere Perspektiven weiblicher Sexualität', in Von der sexuellen Rebellion zur Gen- und Reproduktionstechnologie (Tübingen: Gehrke, 1990), pp. 140-67

Tschurenev, Jana, 'Review of “Material Feminisms” by Susan Hekman and Stacy Alaimo', Das Argument, 52.287 (2010), pp. 414-16

Varikas, Eleni, Nicole Gabriel, and Sonia Dayan-Herzbrun, eds, Adorno critique de la domination. Une lecture féministe (= Tumultes, 23 (2004))

Wolf, Frieder Otto, 'Wider die Kategorie der gesellschaftlichen Naturverhältnisse', Das Argument, 50.279 (2008), pp. 867-72

Woolf, Virginia, Three Guineas (London: Hogarth Press, 1938)

Ziege, Eva-Maria, "The Fetish-Character of "Woman": On a Letter from Theodor W. Adorno to Erich Fromm Written in 1937', Logos, 2.4 (2003) <http://www.logosjournal.com/ issue2.4.pdf> 